classic by the researches of his father. Later on he mapped portions of the Ancient Schists, Old Red Sandstone, and Drifts of Eastern Sutherlandshire. He was anthor of the picturesquelywritten book entitled "Landscape Geology," and of papers on River Action and Glacial Phenomena. Among the more important of these papers the following may be mentioned:- "Tynedale Escarpments : their Pre-glacial, Glacial, and Post-glacial Features," 1880 ; "River Terracing: its methods and their results," 1884; and "On Boulder-Glaciation," 1884." All who enjoyed Mr. Miller's friendship will feel that they have lost a kind-hearted, though keenly sensitive, friend. Strongly imbued with a love of Nature and natural phenomena, he at the same time kept himself in touch with the intellectual life of our time. He leaves a widow and a son, fifteen years of age, who is being educated at Fettes College.

\title{
PROFESSOR LUDWIG RÜTIMEYER, M.D.
}

Foreign Member of the Geological Society of London.

\section{BORN 1825. \\ Died November 26ri, 1895.}

Herr Professor Dr. Ludwig Rütimeyer was born at Biglen in the Commenthal, Canton Bern, in 1825. His father was a parish clergyman, and afterwards Superintendent of the Orphanage at Bonn. Ludwig was educated in the High School and Gymnasium of that town, and in 1842 went to the University of Berne, where he studied theology, with the intention of following his father's profession. - Having developed a taste for comparative anatomy, no doubt partly through the influence of his friend Peter Merian, the Basel Palæontologist, he forsook his theological studies, and took up medicine. Afterwards he visited many of the chief European cities, and in Paris in $\mathbf{1 8 5 0}$ he became acquainted with Elie de Beaumont, and in 1852 he came to London, which he again visited in 1877, In 1854 he took up academical teaching in the Berne University, and in the following year accepted the newly established Chair of Zoology and Comparative Anatomy at Basel, where he remained till his death.

His first work, "Vom Meere bis nach den Alpen," was published on his return from his travels in 1854 ; after this he issued a long series of Memoirs, characterized by the great accuracy and detail of their observations, and the wide philosophical grasp and far-reaching deductions made from them.

Some of the more important of these memoirs are:- "Untersuchungen der Thierreste aus dem Pfahlbauten in der Schweiz," 1860 , in which he gives an account of the earlier races of some of the domestic animals, and shows that while in the Lake-dwellings of Stone Age the remains of wild animals predominate, showing that the inhabitants lived mainly by the chase, in the later settlements, made after the use of metal was discovered, the inhabitants relied chiefly on various domesticated animals for food.

Another important paper is "Beitrage zur Kentnisse der Fossilen Pferde und zu einer Vergleichenden Odontographie der Hufthiere in Allgememen," 1863 ; this may be regarded as laying the foundation 
of that detailed comparative morphology of the teeth, in which the homologies of the several cusps is considered, and from which the American palæontologists have been able to draw very important conclusions as to the phylogeny of many groups of mammals.

In a paper entiled "Ueber die Herkunft unserer Thierwelt eine Zoogeographisch Skizze," 1867, Rütimeyer gives a masterly account of the distribution of the mammalia, showing the relations of the fossil faunas to one another and to the recent forms. It is a testimony to his sagacity that the great additions to our knowledge of this subject have confirmed most of his conclusions, and have rendered very few untenable.

$\mathrm{He}$ was elected a Foreign Member of the Geological Society of London in 1882.

Up to the time of his death Prof. Rütimeyer maintained a lively interest in all scientific researches, and carried on his correspondence to the last. He died at Basel on 26th November, 1895.

\section{E. A. WÜNSCH, F.G.S. \\ Bory 1822. Died November 19Th, 1895 .}

This gentleman was one of the original members of the Glasgow Geological Society, which was founded in 1858 , and he has served the office of Vice-President several times from 1858 to 1881, when he left Glasgow to reside at Carharrack, Scorrier, Cornwall, where he died November 19 th, aged 73 years.

The most important service which he rendered to geological science was his discovery in 1865 of erect trees buried in volcanic ash at Arran. These trees were discovered in the Lower Carboniferous strata of the north-eastern part of Arran in the sea-cliff, about five miles north of Corrie, near the village of Laggan. Here strata of volcanic ash occur, forming a solid rock cemented by carbonate of lime and enveloping trunks of trees, determined by Mr. Binney to belong to the genera Sigillaria and Lepidodendron. Sir Charles Lyell mentions that he visited the spot in company with Mr. Wünsch in 1870 , and saw that the trees with their roots, of which about fourteen had been observed, occur at two distinct levels in volcanic tuffs, parallel to each other, and inclined at an angle of about $40^{\circ}$, having between them beds of shale and coaly matter seven feet thick. It is evident that the trees were overwhelmed by a shower of ashes from some neighbouring volcanic vent, as Pompeii was buried by matter ejected from Vesuvius. The trunks. several of them from three to five feet in circumference, remained with their stigmarian roots spreading through the stratum below, which had served as a soil. The trees must have continued for years in an upright position after they were killed by the shower of volcanic ash, giving time for a partial decay of the interior, so as to afford hollow cylinders into which the spores of plants were wafted. These spores germinated and grew, until finally their stems were petrified by carbonate of lime, like some of the remaining portions of the wood of the original Sigillaria tree-trunks.- "Lyell's Students Elements," 4th edition, 1885, pp. 496, 497. 